\title{
Tunnels and Dikes of the Koolau Range, Oahu, Hawaii, and Their Effect On Storage Depletion and Movement of Ground Water
}

By G. T. HIRASHIMA

CONTRIBUTIONS TO THE HYDROLOGY OF THE UNITED STATES

GEOLOGICAL SURVEY WATER-SUPPLY PAPER 1999-M

Prepared in cooperation with the City and County of Honolulu, Board of $W$ ater Supply, and State of Hawaii, Department of Land and Natural Resources,

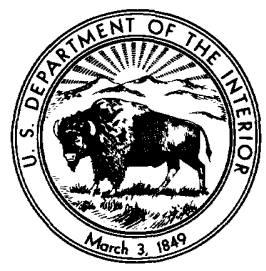
Division of $W$ ater and Land Development 


\section{UNITED STATES DEPARTMENT OF THE INTERIOR}

ROGERS G. B. MORTON, Secretary

\section{GEOLOGICAL SURVEY}

W. A. Radlinski, Acting Director

Library of Congress catalog-card No.77-611466 


\section{CONTENTS}

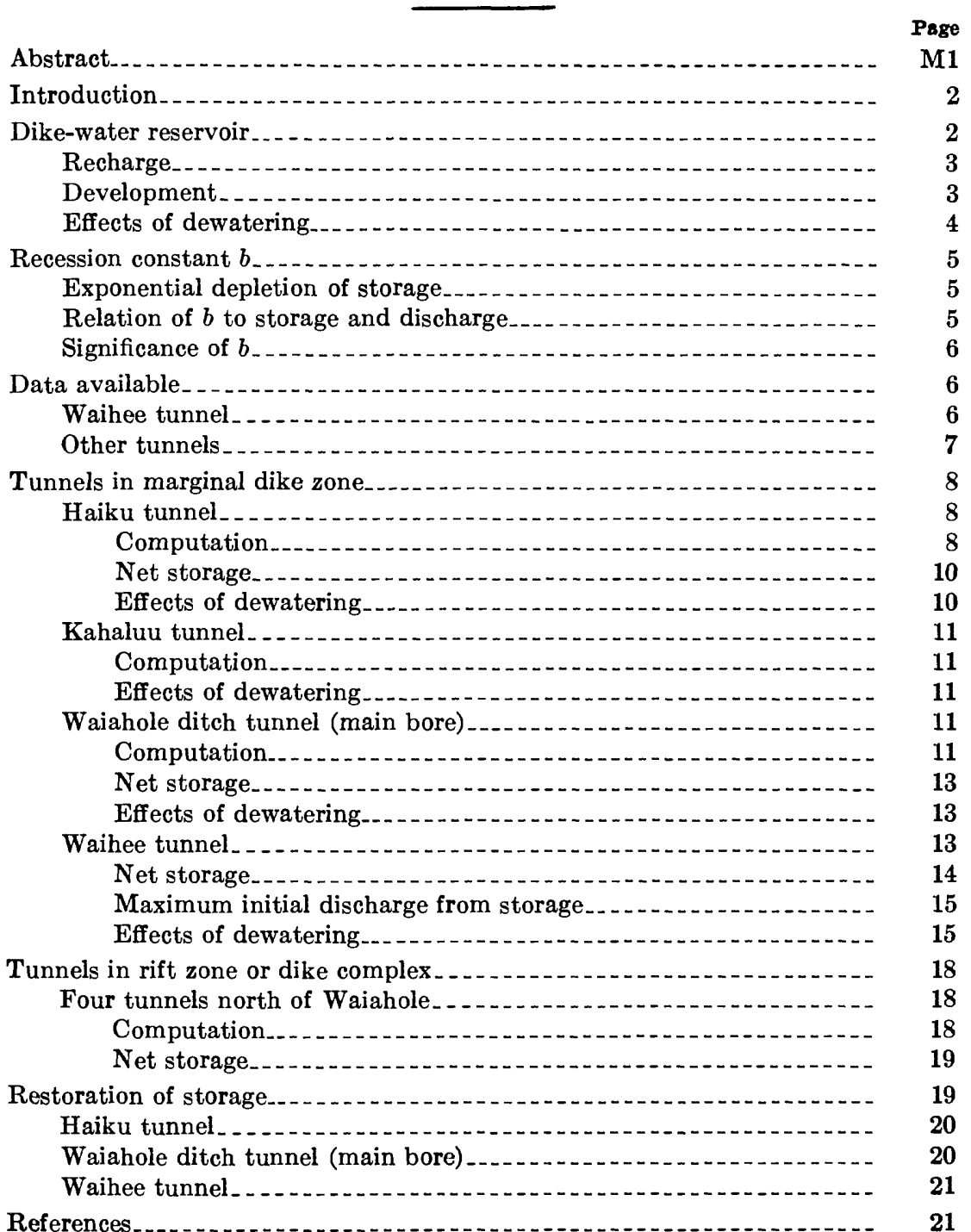




\section{ILLUSTRATIONS}

FrgURE 1. Map of the island of Oahu showing location of report area...-

2. Map showing the location of tunnels in relation to rift (dike complex) and marginal dike zones. ....................

3. Photograph of Waihee tunnel, February 10, 1955, heading at 12-foot dike; water gushing from drill hole through dike....

4. Map of Waihee Valley showing location of Waihee tunnel,

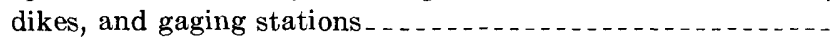

5. Photograph of Waihee tunnel, February 17, 1955, heading 13 feet beyond 12-foot dike; water issuing from lava flow ......-

6. Storage-discharge curve for Waiahole ditch tunnel (main

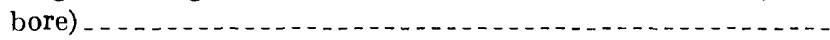

7. Storage-discharge curve for Waihee tunnel

8. Hydrographs of Waihee streamflow for November 1954February 1956

\section{TABLES}

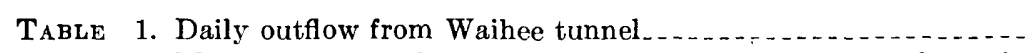

2. Monthly mean discharge of Waiahole ditch tunnel (main bore)

3. Net storage, recession constants, maximum initial discharge from storage, and average base flow for tunnels in marginal dike zone

4. Storage depleted from the four tunnels north of Waiahole....

5. Yield of Waiahole ditch tunnel (main bore) at selected stations on February 4, 1957 


\title{
TUNNELS AND DIKES OF THE KOOLAU RANGE, OAHU, HAWAII, AND THEIR EFFECT ON STORAGE DEPLETION AND MOVEMENT OF GROUND WATER
}

\author{
By G. T. Hirashima
}

\begin{abstract}
Ground water impounded by dikes in the Koolau Range is a major source of water for the island of Oahu, Hawaii, and many tunnels have been bored into the range to develop it.

All water-development tunnels, except Waihee tunnel, have depleted storage in the rocks they penetrate and are now discharging at rates that are but fractions of the rates possible at full storage. Rocks above the floor of the water-development part of Waihee tunnel have never been completely dewatered, and storage can be manipulated by regulating outflow. Thus, storage for this tunnel can be increased during periods of low demand and discharged at high rates during periods of high demand.

A measure of the rate of drainage or depletion of storage is the recession constant $b$ in the recession-curve equation $Q_{t}=\mathrm{Q}_{0} e^{-b t}$. The higher the value of $b$, the faster water can be drawn from storage or returned to storage through artificial recharge. Mathematical analysis of the flow-recession curve of Waihee tunnel shows that (1) its recession constant is $0.00401,(2)$ net storage (exclusive of recharge) is 2,200 million gallons (6,800 acre-feet), and (3) initial discharge from full storage would be about 19 million gallons per day.

Analysis of flow-recession curves for Waiahole ditch tunnel (main bore) and Haiku tunnel shows that these tunnels have drainage characteristics that are similar to those of Waihee tunnel.

The composite recession constant computed for the four tunnels north of Waiahole is about one-third as large as that computed for the Waiahole ditch tunnel (main bore) and the tunnels to the south. The difference is due to an abrupt change in spacing of dikes north of Waiahole. At and south of Waiahole Stream, dikes are spaced tens or hundreds of feet apart; north of Waiahole, they are spaced inches or a few feet apart.

Storage could be restored by bulkheading at the controlling dike or dikes after an analysis is made of the flow-recession curve for each tunnel. Such analyses will show which tunnels are best for storage restoration. The reciprocal of the recession
\end{abstract}


constant is the time, in days, it would take to drain about two-thirds of the storage. The shorter this time is the better storage may be manipulated to meet seasonal peak demands for water.

\section{INTRODUCTION}

Water impounded by dikes in the Koolau Range is a major source of water on the island of Oahu. Many tunnels have been bored into the windward, or northeast, side of the Koolau Range to develop it.

Records of discharge of water-development tunnels show that large quantities of water have been drained from storage. They also show that the rate of discharge at zero storage is but a fraction of the rate at full storage.

One of the problems of water management is the balancing of supply and demand. Because peak demand often is greater than the supply, as is true in northeastern Oahu, storage is necessary. Much of the necessary storage can be effectively provided by restoring storage depleted by water-development tunnels.

The purpose of studies discussed in this report was to determine (1) hydrology of dike-water reservoirs, (2) hydrologic effects of development of dike-impounded water by tunnels, (3) storage depleted by development, and (4) ranges in possible rates of discharge if depleted storage were restored and manipulated.

Studies discussed in this report are limited in scope to large waterdevelopment tunnels bored into the windward, northeast, side of the Koolau Range between Haiku and Kahana Valleys (fig. 1). Previous related studies by Takasaki, Hirashima, and Lubke (1969) are summarized.

The writer acknowledges the Waiahole Water Co. for its cooperation and assistance. This study was done by the U.S. Geological Survey in cooperation with the City and County of Honolulu, Board of Water Supply, and Hawaii Department of Land and Natural Resources, Division of Water and Land Development.

\section{DIKE-WATER RESERVOIR}

The Koolau Range is an erosional remnant of the Koolau volcanic dome, which extended along a rift zone 30 miles long. The rift zone is marked by closely spaced multiple dikes (dike complex). The southern edge of the rift zone presently intersects and underlies the crest of the Koolau mountains north of Waiahole Stream. Owing to deep erosion in the south half of the ancient dome, the crest of the Koolau Range south of Waiahole Stream is southwest of the rift zone and in the marginal dike zone (fig. 2). The marginal dike zone differs from the rift zone in that the dikes are widely spaced. Dikes in the marginal 


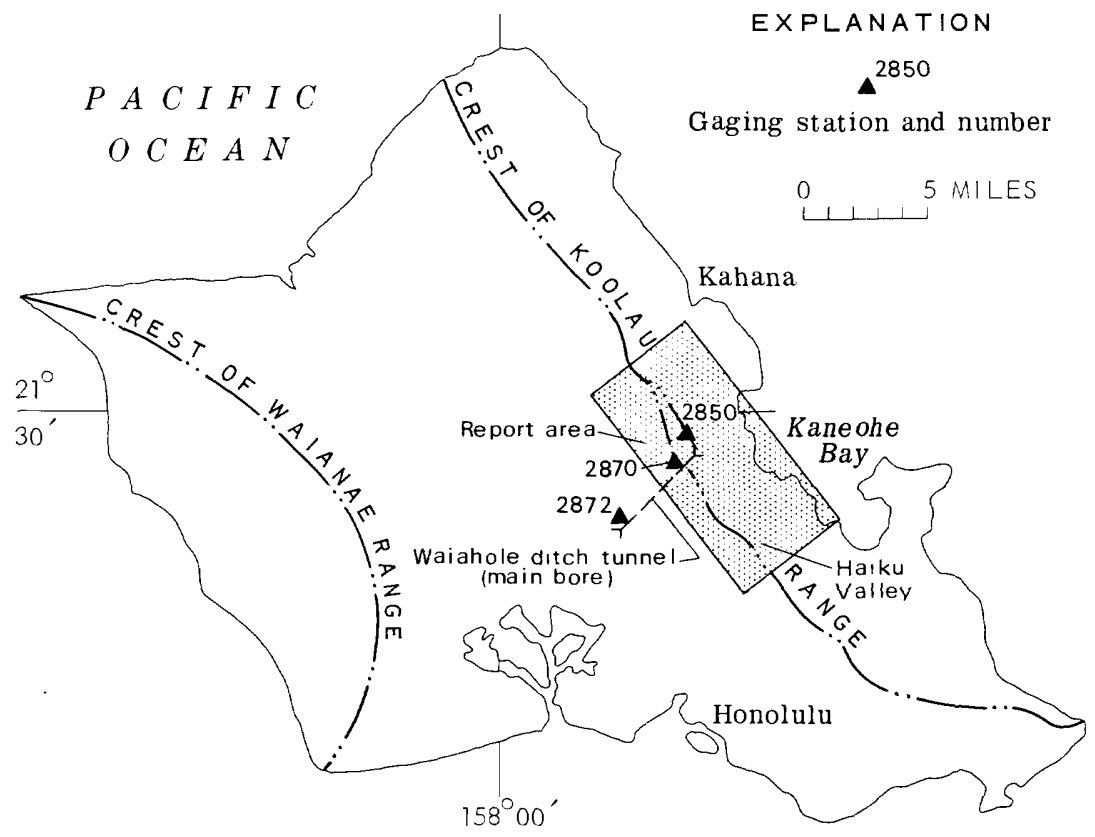

Figure 1.-Location of report area.

dike zone are spaced tens or hundreds of feet apart; in the rif $t$ zone they are spaced inches or a few feet apart.

The vertical basalt dikes are parallel or nearly parallel to the rift zone and are less permeable than the rocks they intrude. Hence, each pair of parallel dikes form two walls of an elongated ground-water reservoir. For more detailed discussions on the rift and marginal dike zones of the Koolau Range, see the report of Takasaki, Hirashima, and Lubke (1969).

\section{RECHARGE}

Persistent trade winds, which blow from the northeast across the Hawaiian Islands, bring large quantities of moist air to the Koolau Range. When these winds are deflected up and over the range, the moisture in the air condenses and falls as rain. The rain that infiltrates the porous ground percolates through the lava to dike-water reservoirs. Under natural conditions, impounded ground water moves along the strike of the dikes to lower altitudes. Where dike reservoirs have been breached by stream erosion, ground water escapes into streams.

\section{DEVELOPMENT}

The Waiahole ditch tunnel (main bore, which penetrates the Koolau Range) was designed primarily as a transmission tunnel to bring the abundant surface water of the windward side of the island to leeward 


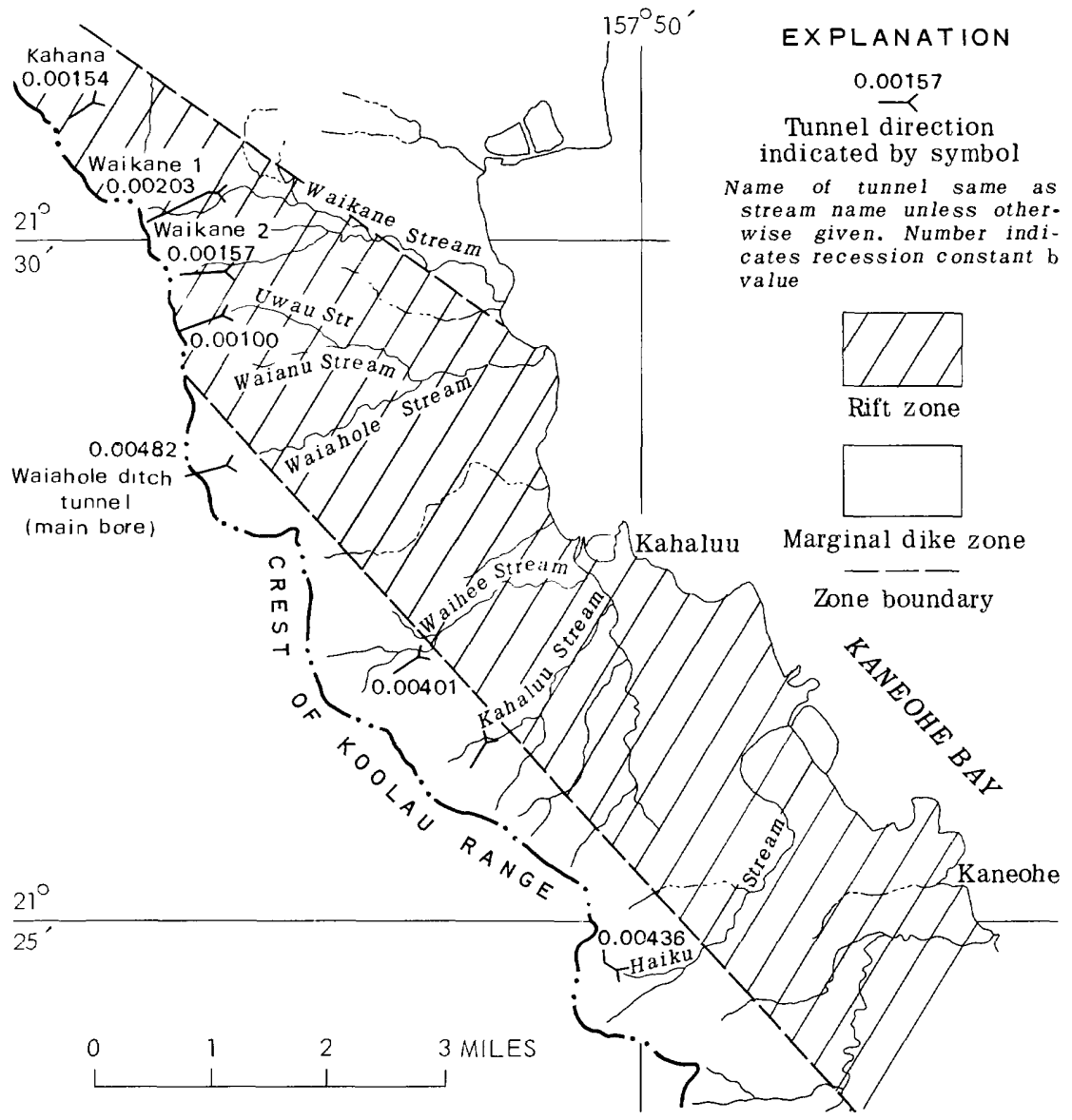

FIGURE 2.-Location of tunnels in relation to rift (dike complex) and marginal dike zones. From Takasaki, Hirashima, and Lubke (1969).

Oahu for irrigation. The tunnel serves, however, both as a waterdevelopment and as a transmission tunnel. It penetrates several dike-water reservoirs, and when it was built in 1913-15, about 16 billion gallons of water was drained from storage (Stearns and Vaksvik, 1935, p. 404).

The success of this tunnel prompted the boring of other tunnels to develop water stored in dike compartments.

\section{EFFECTS OF DEWATERING}

When a tunnel is bored into a dike-water reservoir, the natural relations of recharge, discharge, and storage of the reservoir are upset. The tunnel, if allowed to flow freely, will drain water out of storage and will eventually lower the water level in the reservoir 
to tunnel Jevel. This lowering will cause natural discharge at higher points to decrease or cease. Such effects were caused by the Waihee, Haiku, and Waiahole ditch tunnels discussed later in this report

\section{RECESSION CONSTANT $b$ \\ EXPONENTIAL DEPLETION OF STORAGE}

The hydrograph of daily flow of a tunnel discharging water from storage plotted on semilog paper approximates a straight line. This indicates that the flow recession from a dike-water reservoir is exponential and can be represented by the equation

where

$$
Q_{t}=Q_{0} e^{-b t}
$$

$Q_{t}=$ discharge at any time, $t$,

$Q_{0}=$ discharge at some initial time,

$t=$ time, in days,

$e=$ base of Naperian logarithms, and

$b=$ recession constant.

\section{RELATION OF $b$ TO STORAGE AND DISCHARGE}

The negative sign for the recession constant $b$ indicates decreasing discharge with time. Integrating the recession curve,

$$
S=\int Q_{0} e^{-b t} d t
$$

or

$$
S=\frac{Q_{0} e^{-b t}}{-b}+C
$$

where $C$ is the integration constant.

As the expression $Q_{t}=Q_{0} e^{-b t}$ is the equation for a recession curve at the initial time $(t=0)$, the volume of storage depleted is zero. Substitution in the storage equation gives

$$
\begin{aligned}
& 0=\frac{Q_{0} e^{o}}{-b}+C, \\
& 0=\frac{Q_{0}}{-b}+C,
\end{aligned}
$$

and

$$
C=+\frac{Q_{0}}{b}
$$


Hence, the storage equation gives

but

$$
S=\frac{Q_{0} e^{-b t}}{-b}+\frac{Q_{0}}{b}
$$

$$
Q_{0} e^{-b t}=Q_{t}
$$

therefore,

$$
S=\frac{Q_{0}-Q_{t}}{b}
$$

\section{SIGNIFICANCE OF $b$}

The foregoing equation shows that $b$ is the slope of the linear relation between discharge (plotted as ordinate) and storage (plotted as abscissa). The reciprocal of $b$, however, is the time, in days, for about two-thirds of the storage to be depleted, as shown below.

$$
\begin{aligned}
\Delta S & =\int_{0}^{\frac{1}{b}} Q_{0} e^{-b t} d t \\
& =Q_{0}\left(\frac{e^{-b t}}{-b}\right)_{0}^{\frac{1}{b}} \\
& =Q_{0}\left[\left(\frac{e^{-1}}{-b}\right)-\left(\frac{e^{0}}{-b}\right)\right] \\
& =Q_{0}\left(\frac{1}{b}-\frac{1}{2.72 b}\right) \\
& =Q_{0} \frac{(1-0.368)}{b} \\
& =0.632 \frac{Q_{0}}{b}
\end{aligned}
$$

Because the reciprocal of $b$ is the time it takes for a tunnel to deplete 63.2 percent of storage, $b$ may be used to compare water-yielding qualities of the different tunnels in the study area. Thus, where $b$ is high, a tunnel would be capable of draining water from storage (or restoring water by artificial recharge) in a shorter time than where $b$ is low. Values of $b$ are about three times higher where tunnels penetrate the marginal dike zone than they are where tunnels penetrate only the rift zone. Accordingly, those penetrating the marginal dike zone drain faster.

\section{DATA AVAILABLE}

WAIHEE TUNNEL

A 12-foot dike 1,600 feet from the portal of Waihee tunnel was penetrated on February 8, 1955, and water gushed out at an initial 
rate of about $2.5 \mathrm{mgd}$ (million gallons per day) (fig. 3). Two days later, a temporary gaging station (Waihee water-development tunnel above Waihee gaging station near Waihee, Oahu) was established near the portal (fig. 4) to measure the outflow that, as a result of tunneling past the dike, had increased to $11 \mathrm{mgd}$ (fig. 5) by February 17.

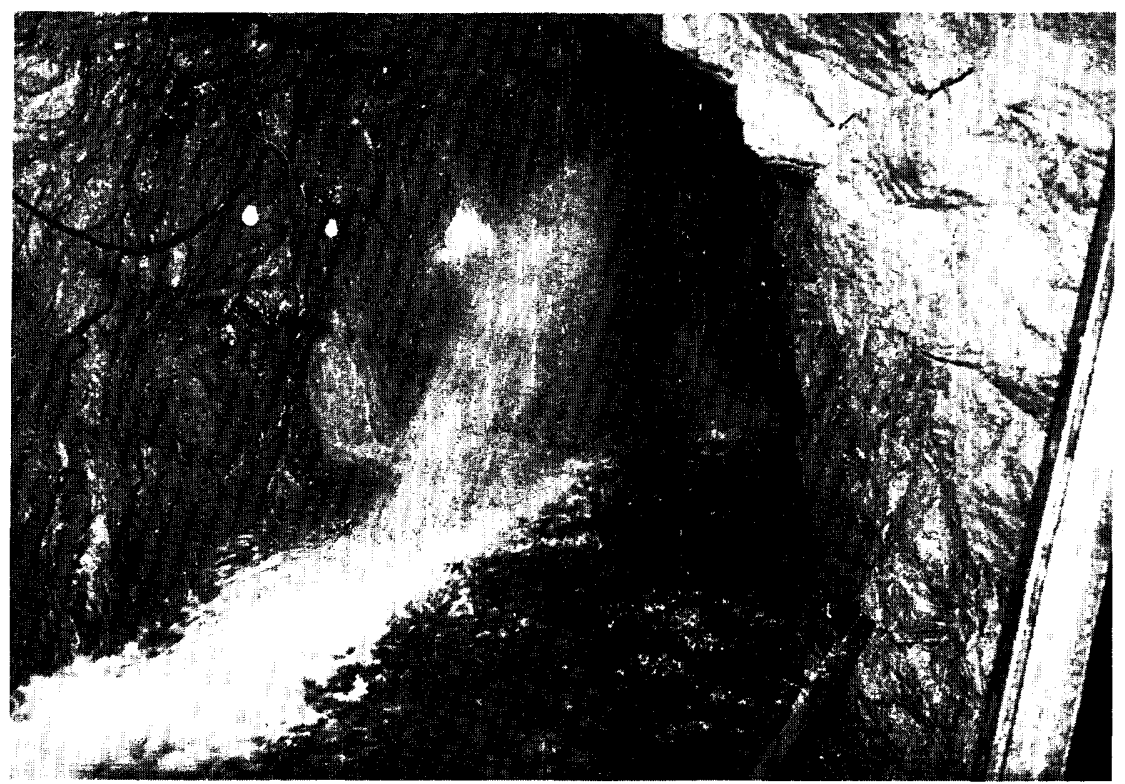

Figure 3.-Waihee tunnel, February 10, 1955, heading at 12-foot dike; water (about $2.5 \mathrm{mgd}$ ) gushing from drill hole through dike.

Operation of this gaging station continued until the distribution pipeline tapping the tunnel was completed. Thus, the figures of daily discharge (table 1) include those for the period of steadily declining discharge after all tunneling was stopped. Records such as these are valuable for determining the slope of the recession curve.

\section{OTHER TUNNELS}

No comparable records are available for the other tunnels discussed in this report. Daily discharge records are available for the Haiku tunnel for the construction period but not for the flow-recession period. Discharges for the flow-recession period, however, were estimated from records collected at the Haiku Stream gaging station. Monthly mean discharges for the Waiahole ditch tunnel (main bore) are available for the flow-recession period (Stearns and Vaksvik, 1935, p. 403). No usable records for Kahalulu tunnel and the four tunnels 


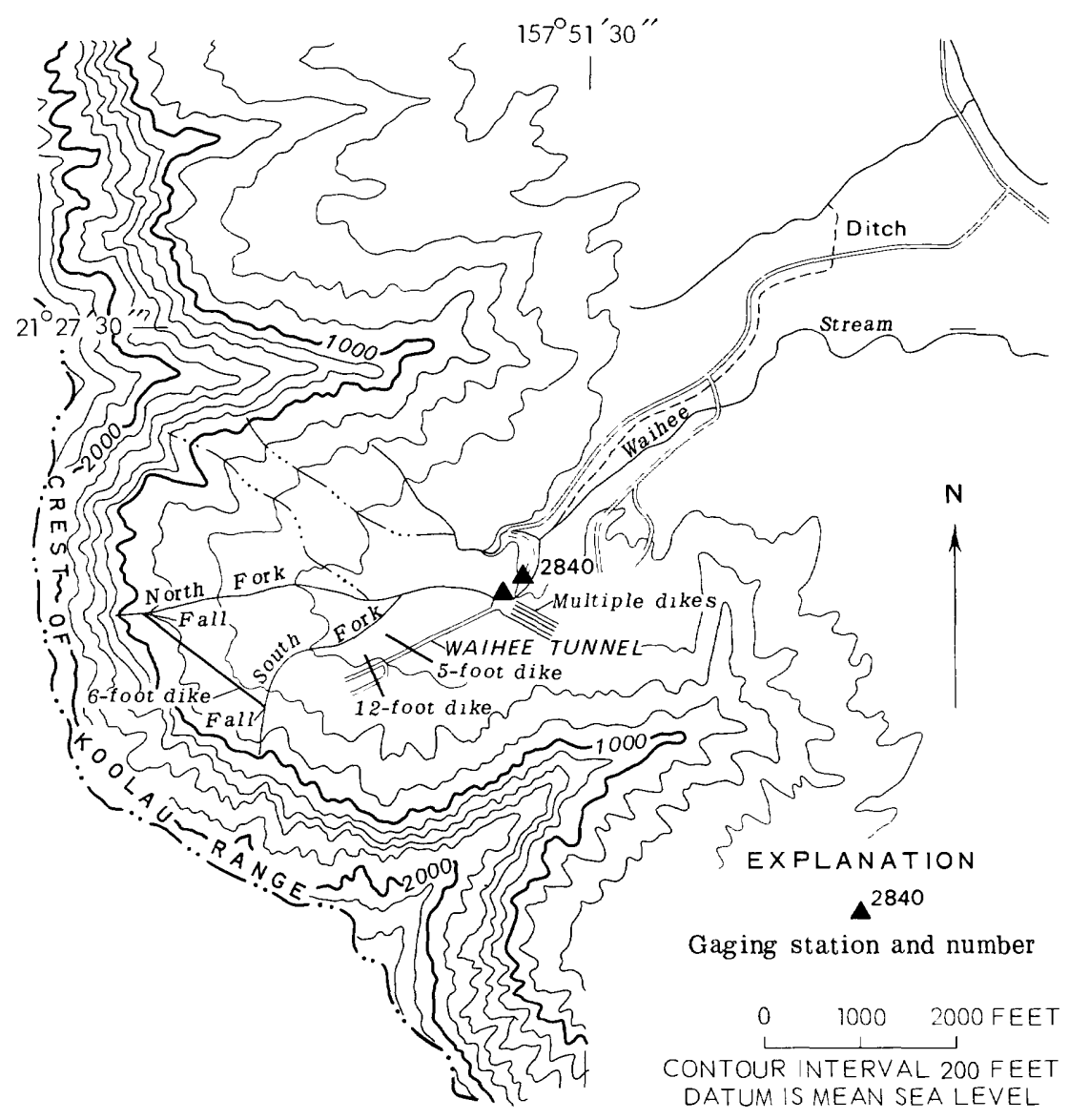

FIgURE 4.-Location of Waihee tunnel, dikes, and gaging stations in Waihee Valley. From Takasaki, Hirashima, and Lubke (1969).

north of Waiahole are available for the initial dewatering period; however, records of daily discharge collected during a period of little or no rain, January 15 to March 11, 1959, were used to define the flow recession.

\section{TUNNELS IN MARGINAL DIKE ZONE}

\section{HAIKU TUNNEL}

\section{COMPUTATION}

Because the Haiku tunnel flow during recession was not measured directly, the recession equation was derived from discharge records for the Haiku Stream gaging station, which include tunnel discharge. The records for the gaging station were adjusted by subtracting the base flow of the stream, $1.3 \mathrm{mgd}$, during the flow-recession period, 


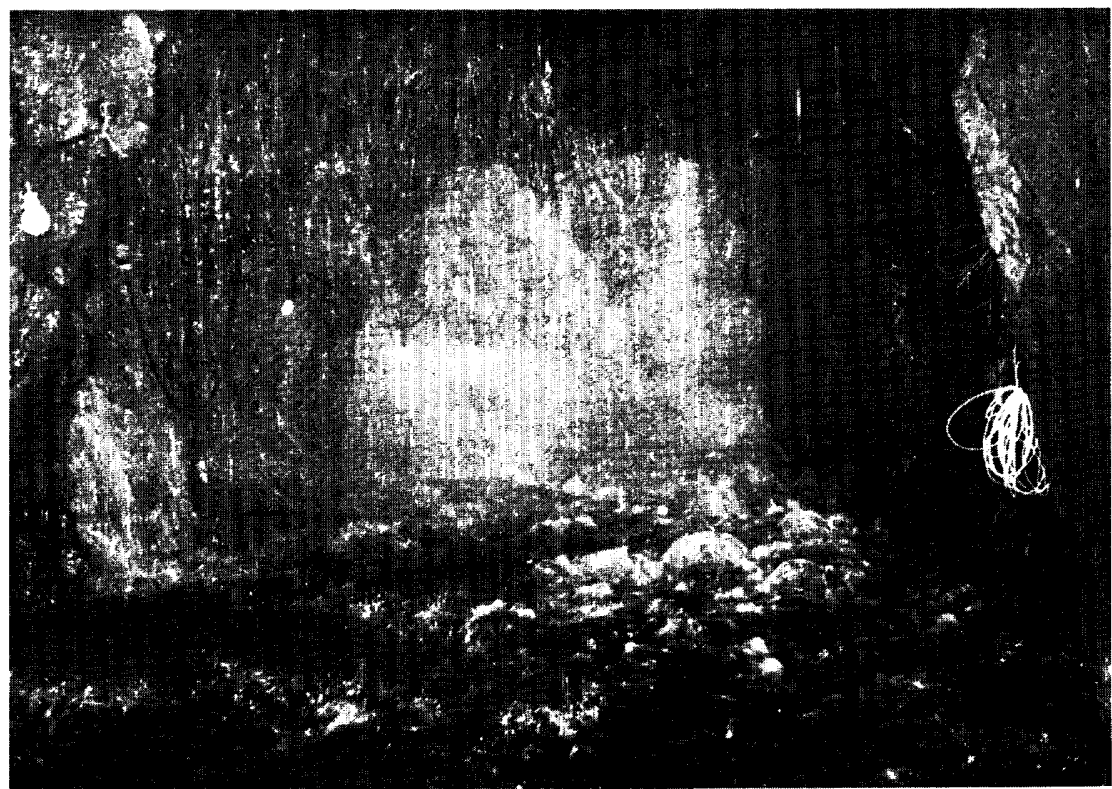

Figure 5.-Waihee tunnel, February 17, 1955, heading 13 feet beyond 12-foot dike; water (about $11 \mathrm{mgd}$ ) issuing from lava flow.

TABLE 1.-Daily outflow from Waihee tunnel

[Discharge, in million gallons per day, Feb. 8 to Dec. 30, 1955]

\begin{tabular}{rrrrrrrrrrrr}
\hline & Feb. & Mar. & Apr. & May & June & July & Aug. & Sept. & Oct. & Nov. & Dec. \\
\hline & & 10.8 & 9.6 & 15.1 & 13.4 & 12.3 & 8.3 & 0.55 & 0.65 & 0.25 & 0.12 \\
& & & & & & & \\
\end{tabular}

1 No gage-height record. Discharge based on current-meter measurements.

2 Station discontinued. 
November 30 to December 13, 1940. The base flow was determined from records for February 6-9, 1941, when all tunnel flow was diverted from the stream.

The Haiku tunnel recession equation was computed by using the discharges for November 30, $10.9 \mathrm{mgd}(12.2-1.3)$ and December 13, $10.3 \mathrm{mgd}(11.6-1.3)$ for $Q_{0}$ and $Q_{t}$, respectively, and 13 for $t$ in the equation $\log Q_{t}=\log Q_{0}+(b \log e) t ; b$ was determined to be 0.00436 , and the recession equation is $Q_{t}=10.9 e^{-0.00436 t}$. This recession equation is probably reasonably accurate because the storage computed by using the equation nearly equals storage as computed from measured and estimated tunnel-discharge volumes. (See following section.)

\section{NET STORAGE}

Volumetric method, quantities in millions of gallons:

$13,576=$ water withdrawn from tunnel by pipeline, April 1941 to December 1958.

$+731=$ water wasted into stream October 1940 to March 1941, during construction of the tunnel.

$+411=$ water wasted into stream, April to July 1941, after pipeline was completed.

$\overline{14,718}=$ water drained by tunnel, October 1940 to December 1958.

$-13,332=$ recharge (average of $2 \mathrm{mgd}$ discharge of tunnel after storage was depleted, multiplied by 6,666 days).

$\overline{1,386}=$ storage.

Equation method, quantities in millions of gallons:

$2,040=$ water drained from 10.9 to $2 \mathrm{mgd}(8.9 / 0.00436=2,040)$.

$-778=$ recharge, $2 \mathrm{mgd} \times 389$ days (time to deplete by equation $\left.Q_{t}=10.9 e^{-0.00436 t}\right)$.

$\overline{1,262}=$ storage depleted from 10.9 to $2 \mathrm{mgd}$.

$+197=$ computed storage depleted before tunnel discharge declined to $10.9 \mathrm{mgd}$.

$\overline{1,459}=$ total storage.

\section{EFFECTS OF DEWATERING}

During construction of the tunnel in November and December 1940, and for several months in 1941, a large quantity of water was drained from storage. Springs above the tunnel ceased flowing, and flow of Haiku Stream decreased. Continued drainage eventually decreased the flow of Kahaluu Stream, 21/2 miles to the north. The average decrease in Kahaluu streamflow from August 1941 to June 1946 was $0.81 \mathrm{mgd}$, or 26 percent (Hirashima, 1962). 


\section{KAHALUU TUNNEL}

\section{COMPUTATION}

Discharge of Kahaluu tunnel during the construction period was determined indirectly from discharge records at the Kahaluu gaging station. As actual tunnel discharges are not known, a precise recession constant could not be determined. The gaging-station data, however, suggest that it is larger than 0.004 .

Water discharging from the tunnel increased the base flow of the stream from $1.7 \mathrm{mgd}$ on August 3, 1946, to $4.4 \mathrm{mgd}$ on September 20, 1946. The flow then gradually decreased to $1.82 \mathrm{mgd}$ on December 13, 1946.

\section{EFFEGTS OF DEWATERING}

The boring of the Kahaluu tunnel lowered the point of discharge of water from springs at altitude 610 feet to tunnel level at 585 feet. This lowering of the discharge point in Kahaluu Valley increased the water yield of the valley by recapturing some of the water that had been diverted by the boring of Haiku tunnel.

\section{WAIAHOLE DITCH TUNNEL (MAIN BORE) COMPUTATION}

An approximate recession constant was computed for the Waiahole ditch tunnel (main bore) from discharge figures compiled by Stearns and Vaksvik (1935, p. 402). Although the two opposing bores of the tunnel did not meet until December 13, 1915, all the dikes had been penetrated by June 15,1915 , and it is assumed that by then the tunnel was draining all dike compartments. The data shown in table 2 were used to define the depletion curve for the tunnel.

TABLE 2.-Monthly mean discharge of Waiahole ditch tunnel (main bore)

\begin{tabular}{|c|c|c|c|}
\hline Date & $\stackrel{t}{t}$ (days) & $\underset{(\mathrm{mgd})}{Q}$ & $\underset{Q}{\log }$ \\
\hline $\begin{array}{l}\text { June } 15,1915 \\
\text { Sept. } 15,1915 \\
\text { Nov. } 15,1915 \\
\text { Dec. 15, 1915 } \\
\text { Jan. 15, 1916 }\end{array}$ & $\begin{array}{r}0 \\
92 \\
153 \\
183 \\
214\end{array}$ & $\begin{array}{l}35 \\
24 \\
17.5 \\
14.4 \\
13.8\end{array}$ & $\begin{array}{l}\text { 1. } 544 \\
\text { 1. } 380 \\
\text { 1. } 243 \\
\text { 1. } 158 \\
\text { 1. } 140\end{array}$ \\
\hline
\end{tabular}

By substituting the values of $t$ and $\log Q$ in the general equation $\left(\log Q_{t}=b(\log e) t+\log Q_{0}\right)$, simultaneous equations were obtained. Their solution shows that $b=0.00458$ and $\log Q_{0}=1.548$. As 1.548 is the $\log$ of 35 (rounded) the equation of the depletion curve from June 15,1915 , is $Q_{t}=35^{e-0.00458 t}$. 
M12 CONTRIBUtions TO THE HYDROLOGY OF THE UNITED STATES

It was previously shown that the storage-discharge equation is $Q_{0}=Q_{t}+b \dot{S}$, where $Q_{t}$ is the intercept and equal to the final stabilized discharge after all storage is depleted. The stabilized discharge of the tunnel was $8.6 \mathrm{mgd}$; therefore, the storage-discharge curve (fig. 6) was drawn with a slope of 0,00458 and an intercept of $8.6 \mathrm{mgd}$.

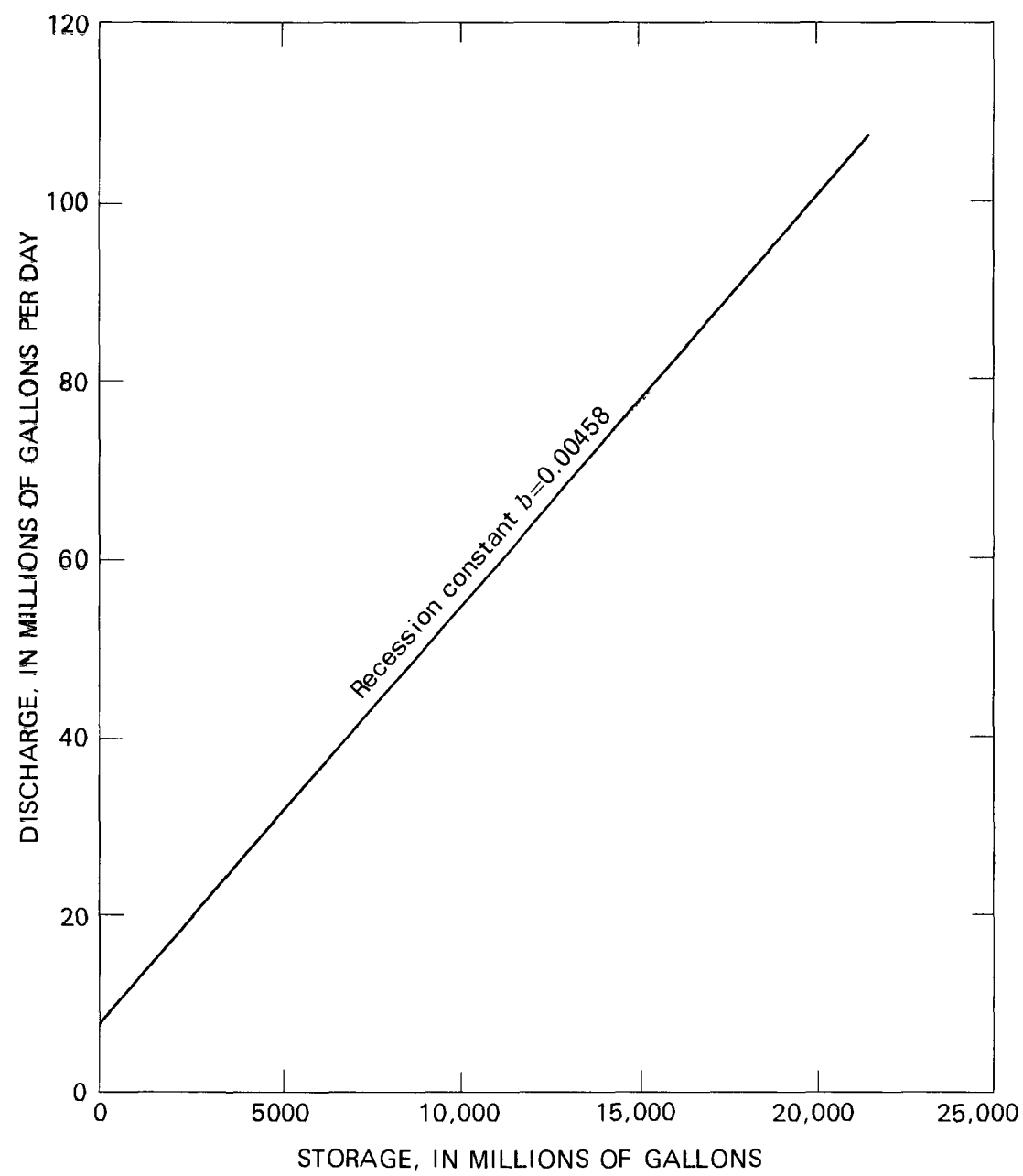

Figure 6.-Storage-discharge curve for Waiahole ditch tunnel (main bore).

Figure 6, as well as figure 7 , shows the relationship of discharge to storage remaining to be depleted rather than the relationship of discharge to storage depleted. 


\section{NET STORAGE}

The total amount of water discharged from the tunnel during August 1913 to June 15, 1915, was computed to be 18,654 million gallons. Net storage was calculated by subtracting from this total all recharge to the system during the same period. Before tunneling was begun from the north end, three springs in Waiahole Valley were discharging 4.7, 1.0, and $2.4 \mathrm{mgd}$ (Stearns and Vaksvik, 1935, p. 403). Two of the springs, having a combined discharge of $5.7 \mathrm{mgd}$, ceased flowing soon after the Waiahole tunnel intercepted their flow. Stabilized flow of the tunnel after completion was $8.6 \mathrm{mgd}$. Thus, the tunnel intercepted $5.7 \mathrm{mgd}$ of water at the beginning of tunneling and $8.6 \mathrm{mgd}$ at the end of tunneling. The average interception of recharge, therefore, is estimated to be the mean of 5.7 and 8.6 , or $7.2 \mathrm{mgd}$. Thus, the water drained from storage before June 15, 1915, was 18,654 million gallons (total water drained) minus 4.924 million gallons (684 days $\times 7.2 \mathrm{mgd}$ ), or 13,730 million gallons.

Storage drained after June 15, 1915, may be computed as follows:

5,750 million gallons $=$ water drained from 35 to $8.6 \mathrm{mgd}$ (fig. 6),

$-2,640$ million gallons $=$ recharge, $8.6 \mathrm{mgd} \times 307$ days $\quad$ (time to deplete, by equation $Q_{t}=$ $\left.35 e^{-0.00458 t}\right)$,

3,110 million gallons = total water drained from storage after June 15.

The total storage depleted, therefore, was $13,730+3,110=16,840$ million gallons.

\section{EFFECTS OF DEWATERING}

When the Waiahole ditch tunnel (main bore) was bored, it intercepted, in addition to the $5.7 \mathrm{mgd}$ from the two springs previously mentioned, the 3-mgd flow of tunnel A 735 feet south of the main bore. Tunnel B, 1,400 feet north of and 5.7 feet higher than the main bore, was dry from the start of tunneling (Stearns and Vaksvik, 1935, p. 405).

\section{WAIHEE TUNNEL}

Because usable daily discharge records during initial dewatering are available for the Waihee tunnel, its recession equation was determined by the least-squares method. The equation $Q_{t}=15.7 e^{-0.00401 t}$ was determined for the postconstruction period, April 23 to May 26, 1955 , by using all the daily discharges for the period. 
M14 CONTRIBUTIONS TO THE HYDROLOGY OF THE UNITED STATES

\section{NET STORAGE}

If Waihee tunnel had not been bulkheaded and its outflow regulated, discharge from the tunnel would have steadily declined until it stabilized. This stabilized discharge, or base flow, was estimated to be $4 \mathrm{mgd}$ for the weather conditions prevailing in 1955. The Waihee tunnel storage-discharge curve was thus drawn with a slope of 0.00401 and an intercept of 4 (fig. 7).

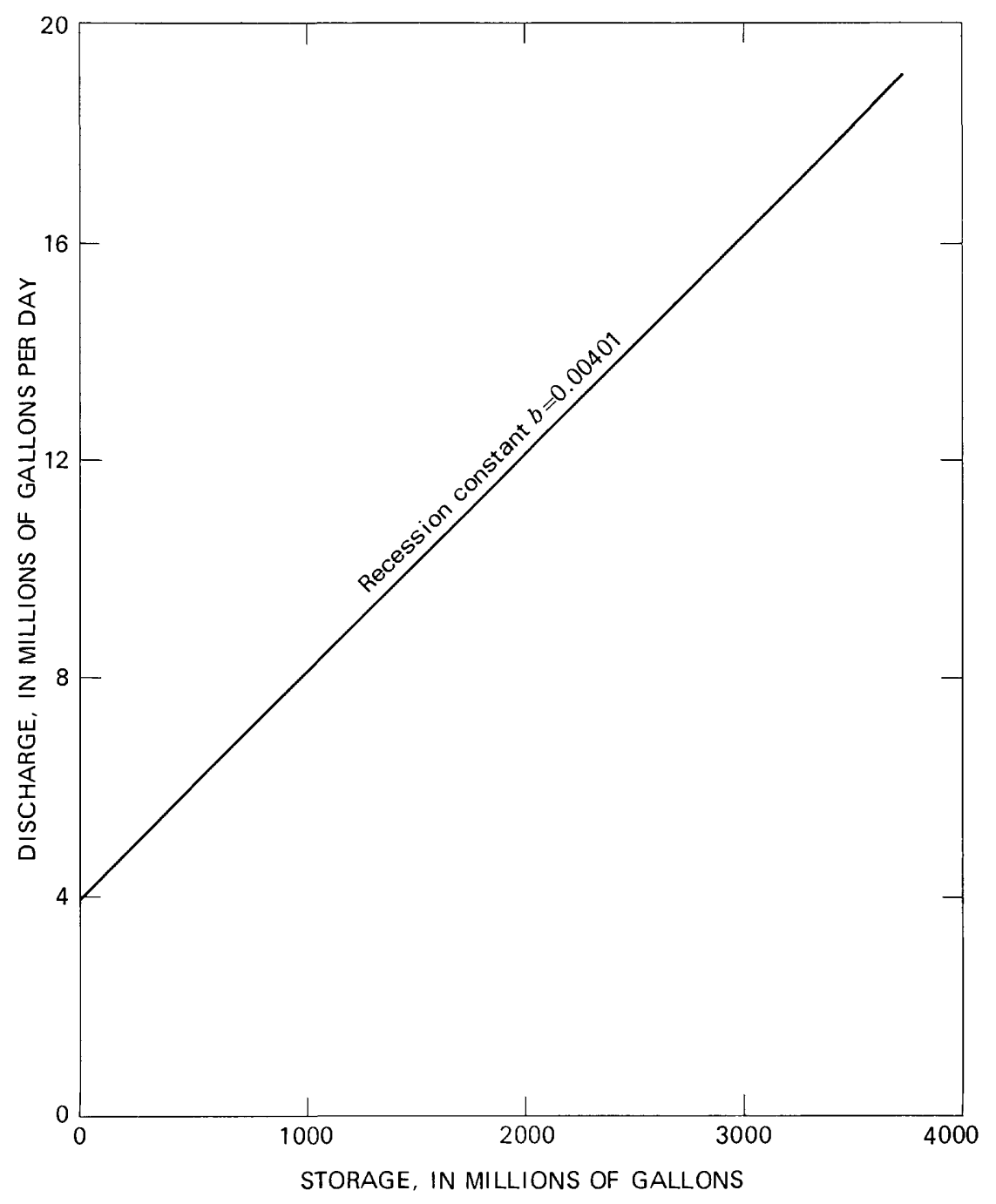

Figure 7.-Storage-discharge curve for Waihee tunnel. 
The volume of water that would have flowed free from Waihee tunnel, beginning with a discharge of $15.7 \mathrm{mgd}$ (after construction stopped) and ending with a stabilized discharge of $4.0 \mathrm{mgd}$, is 2,920 million gallons (fig. 7). Drainage time, computed from the depletion equation $Q_{t}=15.7 e^{-0.00401 t}$, would have been 341 days, and the water drained from storage after construction would have been as follows:

2, 920 million gallons $=$ water drained, -1,364 million gallons = recharge of $4 \mathrm{mgd}$ for $341 \mathrm{days}$,

1,556 million gallons = total water drained from storage, or estimated postconstruction drainage.

The water drained during construction, February 8 to April 23, 1955 , totaled 822 million gallons (table 1), of which 208 million gallons was water recharged to the aquifer. This recharge was obtained by taking the sum of the differences between the estimated normal flow of $6 \mathrm{mgd}$ and the flow remaining in the stream each day (fig. 8, curve C). Subtracting 208 from 822 leaves 614 million gallons-the water drained from storage during construction. Total storage, therefore, is 2,170 million gallons $(1,556+614)$.

\section{MAXIMUM INITIAL DISGHARGE FROM STORAGE}

Because the storage, recession constant $b$, and stabilized discharge are known, the maximum initial discharge from the fully restored reservoir was computed to be $18.9 \mathrm{mgd}$ as follows:

3,716 million gallons $=$ total volume drained $(18.9$ to $4 \mathrm{mgd}$, fig. 7),

$-1,548$ million gallons $=$ volume from recharge; 387 days (time to drain from 18.9 to $4 \mathrm{mgd}) \times 4 \mathrm{mgd}$,

2, 168 million gallons $=$ storage drained.

The computed storage of 2,168 million gallons is almost exactly the storage previously computed, 2,170 million gallons. Thus, it can be assumed that if the tunnel storage is fully restored, the initial freeflow (unregulated) discharge would approximate $18.9 \mathrm{mgd}$.

The maximum initial discharges from storage for the other tunnels were computed in a similar manner and are given in table 3 together with other pertinent data.

\section{EFFECTS OF DEWATERING}

The relation between the flow of Waihee Stream below the tunnel and the flow of Waihee tunnel is shown in figure 8. It shows that the natural flow of Waihee Stream is decreased immediately when water is withdrawn through the tunnel. It also shows that when the tunnel was bulkheaded and outflow was stopped, the natural flow began to 
M16 CONTRIBUtions TO THE HYDROLOGY OF THE UNITED STATES

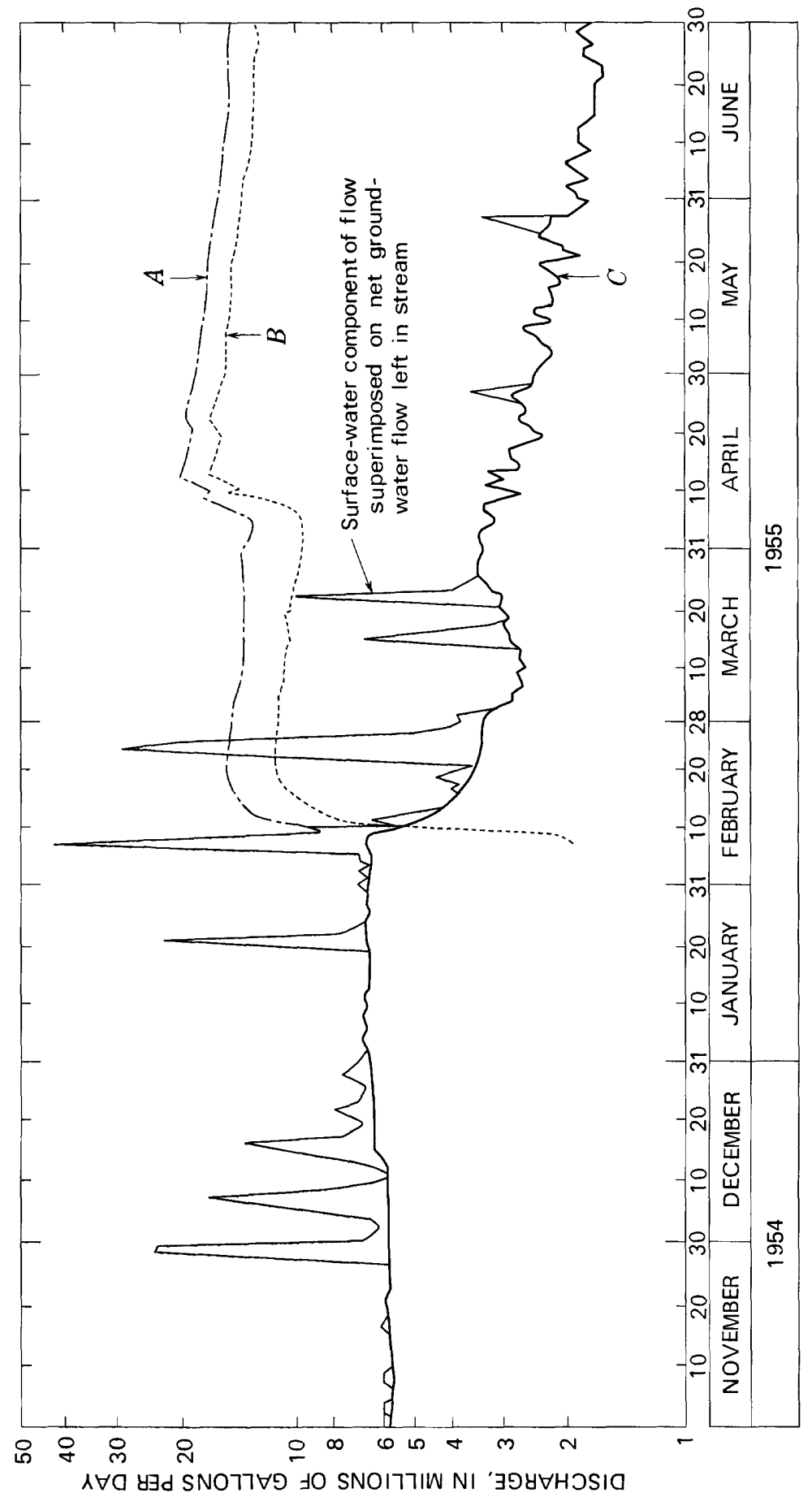


TUNNELS AND DIKES OF THE KOOLAU RANGE, HawaII M17

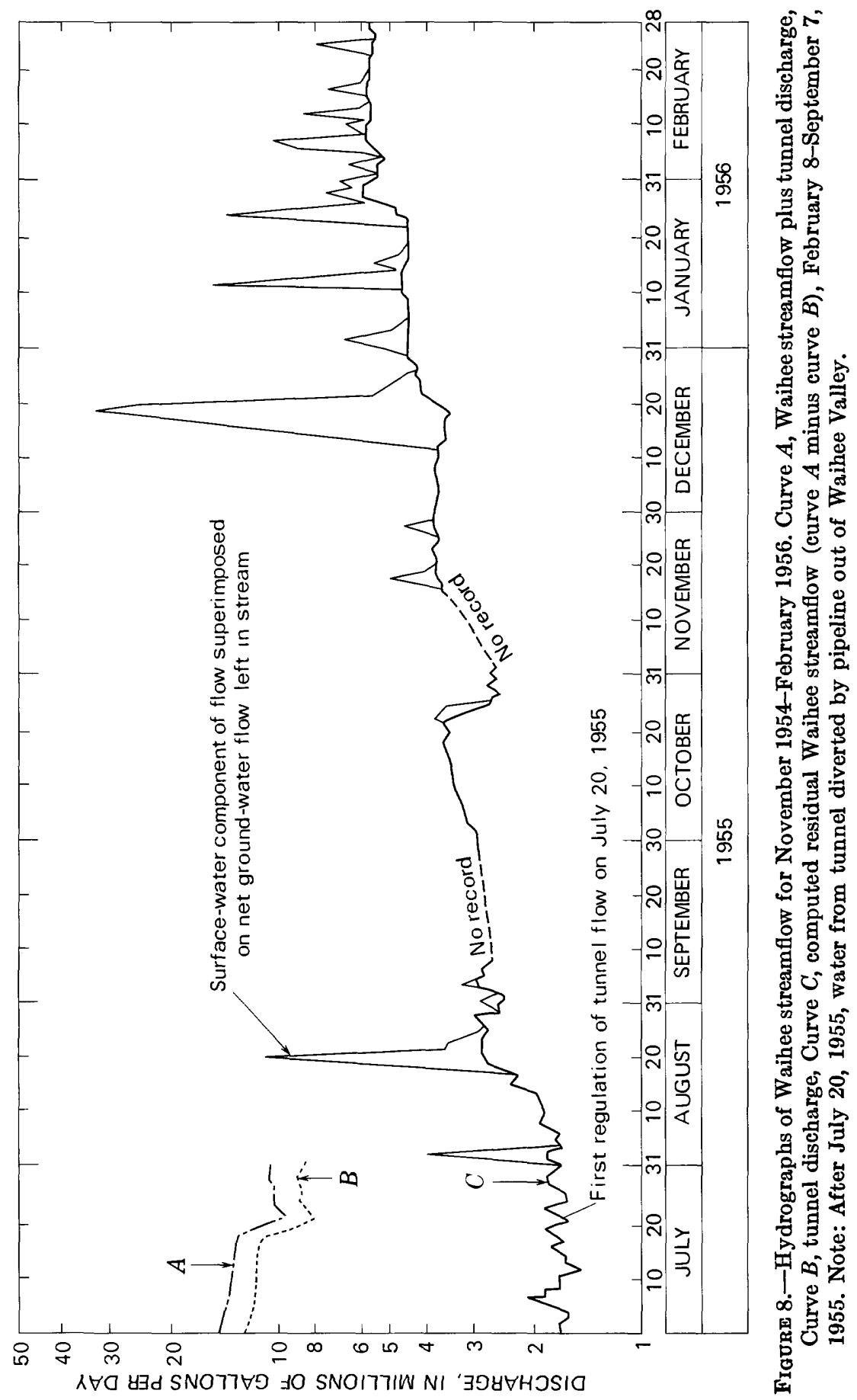


TABLE 3.-Net storage, recession constants, maximum initial discharge from storage, and average base flow for tunnels in marginal dike zone

\begin{tabular}{|c|c|c|c|c|}
\hline Tunnel & $\begin{array}{l}\text { Net storage } 1 \\
\text { (million } \\
\text { gallons) }\end{array}$ & $\begin{array}{l}\text { Recession } \\
\text { constant }(b)\end{array}$ & $\begin{array}{c}\text { Maximum } \\
\text { initial } \\
\text { discharge } \\
\text { from storage } \\
\text { (mgd) }\end{array}$ & $\begin{array}{l}\text { Average } \\
\text { base flow } \\
\text { (mgd) }\end{array}$ \\
\hline Waihee & 2,20 & 0.00401 & 18. 9 & \\
\hline Wahaluhole ditch (main bore) & $\begin{array}{r}170 \\
16,840\end{array}$ & 00458 & 107 & 7. \\
\hline Haiku. & 1,400 & 00436 & 11. 9 & \\
\hline
\end{tabular}

1 Net storage is assumed to be equal to the volume represented by the area under the depletion curve minus the area that is determined by multiplying the final stabilized discharge from the tunnel by the time required to reach that stabilized discharge.

increase. The increase in streamflow shows that even as the Waihee tunnel reservoir is being recharged, some recharge water leaks into the stream. As refilling of the tumnel reservoir continues, a larger and larger part of the recharge water leaks into the stream (curve $C$, fig. 8).

\section{TUNNELS IN RIFT ZONE OR DIKE COMPLEX} FOUR TUNNELS NORTH OF WAIAHOLE COMPUTATION

Usable records of daily flow recessions are not available for the initial dewatering period for the four tunnels of the Waiahole ditch tunnel system; namely, Uwau, Waikane 1 and 2, and Kahana. It was assumed, however, that a fairly long period of little or no rain and steadily declining discharges, January 15 to March 11, 1959, would be a suitable substitute to use in estimating the recession constant of each tunnel. To test this assumption, the recession constant of Waiahole ditch tunnel (main bore) was recomputed, using records for the January 15 to March 11 period.

Because the Waiahole ditch tunnel (main bore) is now primarily a transmission tunnel, ground-water discharge into it is not directly measured. However, the discharge of ground water into the main bore during the January 15 to March 11 period can be estimated by the difference in flow between the north portal and adit 8 gaging stations (2870 and 2872, fig. 1). By using these data, a recession constant of 0.00482 for the main bore was computed. This figure is close to the constant 0.00458 previously computed for this tumnel.

All water from the four tunnels north of Waiahole flows past the Waiahole ditch tunnel at Waianu gaging station (2850, fig. 1). From streamflow records at this station for the January 15 to March 11, 1959, period, a composite recession constant for the four tunnels was computed to be 0.00176 . The drainage time (to deplete twothirds of the storage) for the group of four tunnels $(1 / 0.00176=568$ 
days) is thus about three times that of Waiahole ditch tunnel (main bore) $(1 / 0.00482=207$ days $)$. The longer drainage time suggests that the transmissivity of the rocks penetrated by the four tunnels is less than that of the rocks penetrated by the Waiahole ditch tunnel (main bore) and the other tunnels south of Waiahole.

To show the range of the recession constants and to estimate storage, the recession constant for each of the four tunnels north of Waiahole was computed by using the records for the separate tunnels for the period January 15 to March 11, 1959:

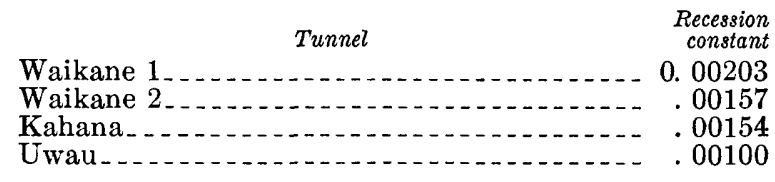

\section{NET STORAGE}

The net storage for each tunnel was estimated from the highest discharge, after the tunnel was completed, and the average stabilized discharge. Storage associated with each tunnel is shown in table 4.

TABLE 4.- Storage depleted from the four tunnels north of Waiahole

\begin{tabular}{|c|c|c|c|c|c|}
\hline \multirow[b]{2}{*}{ Tunnel } & \multicolumn{2}{|c|}{ Interval } & \multirow[b]{2}{*}{$\begin{array}{l}\text { Gross storage of } \\
\text { interval (million } \\
\text { gallons) }\end{array}$} & \multirow[b]{2}{*}{$\begin{array}{l}\text { Recharge ( } Q_{r} \text { in mil- } \\
\text { lions of gallons multi- } \\
\text { plied by days) }\end{array}$} & \multirow[b]{2}{*}{$\begin{array}{l}\text { Net storage } \\
\text { (million } \\
\text { gallons) }\end{array}$} \\
\hline & $\begin{array}{l}\text { Maximum } \\
\text { discharge } \\
(\mathrm{mgd})\end{array}$ & $\begin{array}{l}\text { Average } \\
\text { stabilized } \\
\text { discharge, } \\
Q_{r}(\mathrm{mgd})\end{array}$ & & & \\
\hline $\begin{array}{l}\text { Waikane 1...... } \\
\text { Waikane 2. } \\
\text { Kahana } \\
\text { Uwau. }\end{array}$ & $\begin{array}{r}10.2 \\
6.9 \\
15.1 \\
16.8\end{array}$ & $\begin{array}{r}5.2 \\
1.2 \\
3.8 \\
10.8\end{array}$ & $\begin{aligned} & 5,020-2,560=2,460 \\
& 4,390-760=3,630 \\
& 9,810-2,470=7,340 \\
& 16,800-10,800=6,000\end{aligned}$ & $\begin{aligned} 5.2 \times \quad 331 & =1,720 \\
1.2 \times 1,114 & =1,340 \\
3.8 \times \quad 893 & =3,390 \\
10.8 \times \quad 440 & =4,750\end{aligned}$ & $\begin{array}{r}740 \\
2,290 \\
3,950 \\
1,250\end{array}$ \\
\hline Total & & & & & 8,230 \\
\hline
\end{tabular}

\section{RESTORATION OF STORAGE}

Restoration of storage by bulkheading at points where a dike or dikes have been breached by a water-development tunnel is desirable because water demands are seasonal. The seasonal nature of demand, in turn, requires that water stored during periods of low demand be made available at high-discharge rates to meet peak demands. Because the high $b$ tunnels drain faster, water stored in them may be withdrawn in a shorter time than that from low $b$ tunnels. For example, Waihee tunnel $(b=0.00401)$ will drain two-thirds of its storage in 218 days $(1 / 0.00401)$, whereas Kahana tunnel $(b=0.00154)$ will drain two-thirds of its storage in 650 days. 
High $b$ tunnels of the Koolau Range are better candidates for storage restoration for the additional reason that cost of effective bulkheading may be considerably less than for low $b$ tunnels because the dikes are widely spaced. For example, in the Haiku tunnel, four dikes were intercepted in about 1,300 feet of tunnel. But most of the storage was depleted from behind the dike 1,200 feet from the portal, so that only one or two bulkheads are needed to effectively restore the depleted storage. Low $b$ tunnels in the Koolau Range, by contrast, intercepted many more dikes, and to effectively restore depleted storage would require many and separately valved bulkheads.

\section{HAIKU TUNNEL}

Haiku tunnel has a high $b$; therefore, further restoration of storage should be considered. A bulkhead was placed at the site of a dike 600 feet from the portal, and a small part of the original storage was restored. To further increase storage, however, additional bulkheads are needed, especially one at the site of the 10-foot dike 1,200 feet from the portal, which, when penetrated during construction, yielded the most water. If the additional bulkhead is installed, it should be valved separately from the one 600 feet from the portal. If storage were fully restored, initial discharge from storage would be about, $11.9 \mathrm{mgd}$.

\section{WAIAHOLE DITCH TUNNEL (MAIN BORE)}

Storage of more than 16,000 million gallons $(49,000$ acre-feet) of water is associated with Waiahole ditch tunnel (main bore). If this storage were restored, initial discharge from storage would approximate $107 \mathrm{mgd}$. Flow measurements on February 4, 1957, throughout the length of the main bore show that inflow in the 1,413-foot interval between the north portal of the tunnel and north portal gaging station was $2.44 \mathrm{mgd}$, or 37 percent of inflow between the north portal gaging station and adit 8 (south portal). (See table 5.)

Monthly discharge records furnished by the Waiahole Water Co. show that the long-term difference in discharge between the north portal and south portal gaging stations is $5.25 \mathrm{mgd}$. The long-term inflow into the main bore from the north portal of the tunnel to adit 8 , therefore, is about $7.2 \mathrm{mgd}(5.25 \mathrm{mgd} \times 1.37)$.

The main bore serves as a transmission tunnel; therefore, provision would have to be made for a conduit to carry water if the tunnel were to be bulkheaded. Valved openings at dikes could be provided. Accurate measurements should be made of the flow from major dike compartments, and only those dikes impermeable enough and high enough to allow maximum storage should be considered for bulkheading. Flow measurements (table 5) showed that inflow to the 
TABLE 5.-Yield of Waiahole ditch tunnel (main bore) at selected stations on February 4, 1957

\begin{tabular}{|c|c|c|c|c|c|}
\hline Station & $\begin{array}{l}\text { Distance } \\
\text { from north } \\
\text { portal (ft) }\end{array}$ & $\underset{(\mathrm{mgd})}{\text { Discharge }}$ & $\begin{array}{c}\text { Distance } \\
\text { between } \\
\text { stations } \\
\quad(\mathrm{ft})\end{array}$ & $\begin{array}{l}\text { Inflow } \\
\text { between } \\
\text { stations } \\
(\mathrm{mgd})\end{array}$ & Remarks \\
\hline North portal... & & & & & $\begin{array}{l}\text { All water turn } \\
\text { out of tunne } \\
\text { at north } \\
\text { portal. }\end{array}$ \\
\hline $\begin{array}{l}\text { Waiahole tunnel at north portal gaging } \\
\text { station. }\end{array}$ & 11,410 & 2.44 & 1,410 & 2.44 & \\
\hline $\begin{array}{l}\text { Dike } 11 \\
\text { Dike } 13 .\end{array}$ & $\begin{array}{l}11,980 \\
13,040\end{array}$ & $\begin{array}{l}\text { 3. } 64 \\
5.49\end{array}$ & $\begin{array}{r}570 \\
1,060\end{array}$ & $\begin{array}{l}1.20 \\
1.85\end{array}$ & $\begin{array}{l}\text { 5-foot dike. } \\
\text { 5-foot dike. }\end{array}$ \\
\hline Dike 15 & 13,825 & 8. 40 & 785 & 2.91 & 10-foot dike. \\
\hline South portal gaging station (at adit 8).... & 14,567 & 8.98 & 10,742 & .58 & \\
\hline $\begin{array}{l}\text { Inflow between north portal and north } \\
\text { portal gaging station. }\end{array}$ & (n) & (2........ & 14,567 & $\begin{array}{r}8.98 \\
-2.44\end{array}$ & \\
\hline Inflow between gaging stations.... & 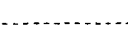 & & 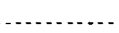 & 6.54 & \\
\hline
\end{tabular}

1 Estimated with odometer.

tunnel (2.91 mgd) was greatest between dikes 13 and 15. This section of the tunnel probably should be the first to be bulkheaded.

\section{WAIHEE TUNNEL}

The restored storage is a significant amount in Waihee tunnel. About 2,200 million gallons can be restored by regulating the outflow from the tunnel, and to meet demands, water can be withdrawn from storage at rates much higher than the $3.4 \mathrm{mgd}$ available at zero storage (Hirashima, 1965).

\section{REFERENCES}

Hirashima, G. T., 1962, Effect of the Haiku tunnel on Kahaluu Stream, Oahu, Hawaii in Short papers in geology and hydrology: U.S. Geol. Survey Prof. Paper 450-C, p. 118-120.

- 1965, Effects of water withdrawals by tunnels, Waihee Valley, Oahu, Hawaii: State of Hawaii Div. Water and Land Devel. Rept. R28, 38 p.

Stearns, H. T., and Vaksvik, K. N., 1935, Geology and ground-water resources of the island of Oahu, Hawaii: Hawaii Div. Hydrography Bull. 1, p. 399-409. Takasaki, K. J., Hirashima, G. T., and Lubke, E. R., 1969, Water resources of windward Oahu, Hawaii: U.S. Geol. Survey Water-Supply Paper 1894, 119 p. 